\title{
Rules and Practices of Forensic Experts in the Field of Civil or Criminal Law
}

Sedat Krasniqi

\author{
PhD. College, "FAMA" Pristina, Prizren, Mitrovica, Gjilan, Faculty of Law \& Criminalistic \\ Association of Forensic Sciences - Center for Forensic Science Expertise Executive Director, Criminalistic \& Forensic \\ Expert, Republic of Kosovo.
}

\begin{abstract}
The process of conducting an examination (by the expert) ends - de facto, with the submission of a written report (the act of expertise) to the court, while - de jure, it is considered to have been completed only when the question and answer session it is held before the court. Although in actual practice it is found that there are generally no strict requirements regarding the structure of the expert acts, the statement of facts, supporting evidence, their analysis and justification of the expert's approach to the conclusions reached are indispensable, both for the court and the parties, to appreciate the value of the expert's opinion and why not, to professionally list the expert in relation to other specialists in the field. Paragraph 1 of Article 230 of the Code of Civil Procedure clearly states that "The opinion of the expert must be reasoned".
\end{abstract}

Keywords: Forensic. experts, practices, criminal law, expert, assignment, rules)

\section{Introduction}

It is important to note that the court should accept the expert's opinion as a source of evidence only when reached conclusions are scientifically substantiated. The requirement not to allow practices where expert evaluation is accepted and take as completely reliable, without a necessary verification analysis, scientific basis, expert conclusions or without an analysis of the facts on which the conclusion is based, should engraved on the desk of any judge, prosecutor or lawyer ${ }^{1}$.

Of course, in order to have quality expertise with scientifically accurate conclusions, the ethical-professional level of the expert profile would be at the essence of the matter.

But!

How are experts assigned to carry out expertise or re-expertise in current practice?

Does the way the expert is assigned influence the level of conclusions reached?

Are the experts distinguished from each other in carrying out certain expertise?

Why is it that different experts come to different conclusions about the same materials examined?

Are there ways of act to maximize the quality of the expertise and the conclusions reached?

Understanding forensic expertise as proof

All the activity of the criminal prosecution authorities is governed by the principle of legality, strict adherence and without any derogation from the established legal order, adhering to the requirement that the judicial decision in any given case correspond to the truth, the finding of fact and the concrete circumstances of the case in full accordance with objective

\footnotetext{
1 Sedat Krasniqi PhD, University Lecturer in Criminalistics, College "FAMA" -Prishtina, Criminal Expert. "Center for Forensic Science Expertise" - Association of Forensic Sciences, Executive Director, Kosovo, 2016.
} 
reality.

Expertise as judicial and procedural action is, in our country as well as in the world, a wealth of modern justice. In the process of determining material truth, the court is increasingly relying on the opinions of experts in the field of litigation.

In criminal proceedings, the performance of this duty may not be accomplished otherwise, except by means of the types of evidence and means of inquiry required by the legislator in Articles 153-226 of the Code of Criminal Procedure1.

The opinions of experts in various fields are an important condition in criminal proceedings, from preliminary investigation to judicial review, shedding light on the range of facts and evidence provided.

In preliminary investigative and forensic investigations, the problems related to forensic expertise are widespread and contain aspects of a special and general character. But in order to group them according to their affiliation, we could list three main issues, which are:

The entity carrying out the expertise

Material as an object of expertise

The process of examining the object by the expert ${ }^{2}$

\section{Expert Assignment}

The ways in which legal experts are assigned to criminal or civil proceedings are clear, but in current practice we find that the way they are assigned is still a minor problem, which often has major consequences.

In the Albanian environment (Albania and Kosovo), forensic experts exercise their duty under the following conditions:

a. experts at public institutions that carry out the expertise are part of the standard procedures of their work (eg institutions like : Institution of Scientific Police, Institution of Forensic Medicine and Kosovo Forensic Agency);

b. employees of different levels in public institutions who do not have expertise in their work procedures (eg lecturer in electronics, assigned to perform audio-video technical expertise;,... etc.);

c. freelance and independent experts with special knowledge in certain fields acquired during their professional careers, licensed and registered with the relevant authorities.

So, in its need to provide expert evidence in a particular field, the court should turn to one of these three sources, not to mention a fourth source who are experts or expert institutions abroad who will not be analyzed in this material. While the court in its petitions to one or the other source addresses the expectation that the experts are competent, independent and impartial, it is found that there are problems with the ethical-professional level of the experts and often some kind of depravity in their use.

In each of the three sources cited above, issues regarding expectations of the expert have been identified, which we consider to be "risk points" in the expert's ethical-professional competences and which the court must necessarily consider 3 .

In Judicial practice in Kosovo, the issue of dealing with the problem of appointing experts to perform forensic expertise is regulated by the relevant legislation and laws covering this very important and equally important area of our justice system. Within the Kosovo Judicial Council, there is a list of forensic experts of various profiles, who carry out the expertise as requested by the Courts throughout the Republic of Kosovo and wide. The expertise is of course performed by judicial decisions, and at the request of the parties or their authorized defense counsel in both civil and criminal matters, providing

\footnotetext{
${ }^{1}$ Kodi i procedures penale I Republikës së Shqipërisë, Tiranë 2004, f. $83-117$.

2 Dr.Fatmir Tartale, Ekspertimi si prove në procedimin penal, Tiranë 2008, f 13-14

${ }^{3}$ Sedat Krasniqi, PhD, University of Sarajevo, Faculty of Criminalistics, Criminology and Security Studies, Sarajevo BiH, 2016/17.
} 
professional and scientific services (expertise, opinions and findings), argued by more modern and standard methods of international levels ${ }^{1}$.

In the Criminal Procedure Code of the Republic of Kosovo Nr. 04 / L-123, Articles 136 to 142 of the Code, regulate the duties and powers of expertise's and experts in litigation, both in civil and criminal cases.

For the use of expertise by the State Prosecutor the guilt or innocence of the defendant or the degree of damage caused by a criminal offense must be questioned, the answer to the question under sub-paragraph 1.1 of this paragraph can only be given by specialized or technical expertise. The expert must have specialized experience or training that is relevant and current, the expert must have analyzed the evidence provided legally, during the expertise, the expert must have used generally accepted practices in his field or have a scientific basis or technical and the expert should draft a report summarizing the methods of analysis used and the conclusions.

The expert cannot express his or her opinion on the guilt or innocence of the defendant. The defendant or his or her defense counsel may request the state prosecutor to obtain a statement from the expert, the victim or the victim's defense counsel may request from the state prosecutor to receive a statement from the expert.

The decision to engage an expert, of course, prior to the expert's engagement, the state prosecutor issues a decision in which the expert presents specific written questions or a series of questions that are relevant to the defendant's guilt or innocence or the degree of damage caused by the criminal offense, and specifies the name of the expert and provides the basis for the expert's specialized expertise, including his / her education, experience and previous service as a court expert; and provides the expert with access to the appropriate evidence for specialized or technical expertise.

The defendant, defense counsel, victim or victim counsel may challenge an expert's selection based on his or her qualifications or potential conflict of interest by submitting an objection to the pre-trial judge. The pre-trial judge shall rule on the expert's selection within ten (10) days after the expert appointment.

If any particular type of expertise falls within the scope of any professional institution or expertise can be done within a particular public authority, this task, especially if it is a complex task, is normally entrusted to such professional institution or public authority. The professional institution or public authority shall designate one or more experts to carry out the expertise. Where possible and if no conflict of interest arises, the experts shall be appointed by the professional institutions or public authorities which provide their experts when so required.

If the expert in question is employed by the Government of Kosovo as a forensic expert or forensic examiner, he shall apply the specialized expertise as determined by law, order of the court or order of the state prosecutor or the public authorities lack the relevant expertise, the expert with the relevant expertise is engaged and compensated by public funds. The expert's expenses are added to the costs of the procedure. The expert shall apply the expertise without delay and shall submit to the state prosecutor a written report of the expertise in accordance with Article 138 of this Code.

The expert report contains: data on the expert's identity and data on the investigation; important questions concerning the guilt or innocence of the defendant or the extent of the damage caused by the offense; expert experience and training, reasons why these are relevant and how relevant that experience or training is; a description of the evidence being analyzed; a description of the expertise, including relevant photographs, drawings, summary tables, radioscopy, images, laboratory results or other scientific or technical data that are relevant. explaining that analytical practices are generally accepted in the expert field or have a scientific or technical basis; and the conclusion that presents the expert's opinion on the questions in paragraph 2 of this article, or which explains why the answers to those questions have not been answered.

The expert does not express his opinion on the guilt or innocence of the defendant in the report. The expert report which is not in accordance with this article is not acceptable. or his defense counsel and the injured party not less than five (5) days before the commencement of the expert pre-trial hearing, but not later than ten (10) days after the state prosecutor has received the expert's report.

Autopsy is performed by a qualified medical examiner on the order of the state prosecutor. Autopsy cannot be trusted by the physician who treated the deceased. The Ministry of Justice issues guidelines and standards regarding autopsy may

\footnotetext{
${ }^{1}$ Sedat Krasniqi PhD, Ligjerues universitar në lëndët e Kriminalistikës, Kolegji "FAMA"-Prishtinë, Ekspert Kriminalist "Qendra për Ekspertime Shkencore Kriminalistike" - Shoqata e Shkencave Ligjore, Drejtor Ekzekutiv, Kosovë, 2016.
} 
be ordered by the state prosecutor. If the defendant does not give written consent to give a blood sample, bodily tissue, DNA or the like, or fails to give written consent to undergo a physical examination of the injuries as required in the investigation, the state prosecutor shall request from the pre-trial judge to issue the order for the sample to be taken or for examination in accordance with Article 144 of this Code.

Samples taken in accordance with the order referred to in paragraph 3 of this Article may be subject to molecular and genetic examination insofar as such measures are necessary to establish the origin or to establish whether the traces found are of the defendant or the injured. Such molecular or genetic screening can only be carried out at the pre-trial judge's order. If medical records are likely to contain information relevant to the criminal procedure, the state prosecutor requires the pre-trial judge to issue an order that the records be are given to the state prosecutor. Pre-trial expert's statement.

The expert may be summoned to testify at the pretrial hearing if: the opinion given in the expert's report supports the inference of the defendant's guilt; the opinion given in the expert report supports the conclusion on the defendant's innocence; the opinion given in the expert report supports the conclusion that identifies the defendant, victim, or other person relevant to the investigation; or the opinion given in the expert report supports a conclusion that is relevant to the investigation.

The defendant or victim may accept the conclusions of the expert's report. If all parties agree with the conclusions of the expert's report, this shall be noted in the record and no statement shall be taken. The expert is questioned by the state prosecutor, defense counsel, victim and victim advocate. The report, transcript or recording of the statment are attached to the case file.

The defendant may request the state prosecutor a request for expertise relevant to his defense. If the state prosecutor refuses, the defendant may challenge this ruling with the pre-trial judge. The defendant may receive and pay itself for expertise. The expert shall comply with section 138 of the present Code and the state prosecutor shall receive a copy of the report of the defense expert within fourteen (14) days of its completion. Conflicts between experts, If the data in the expert's findings differ substantially, or when their findings are unclear, incomplete or in contradiction with themselves or with the circumstances considered, and if these deficiencies cannot eliminated by re-examining the experts, the opinion of other experts may be required ${ }^{1}$

\section{Does the way in which the expert is assigned influence the level of conclusions reached}

Of course, a very important role also appears in the phase of appointing experts to perform their various professional and scientific expertises. It is natural for the expert to make the conclusions that are influenced by the level of experts (expert), his / her professional background, scientific level, academic rank, as well as the professional experience of practicing the profession in the given field of expertise. In special cases, it is often the case that experts have different conclusions, opinions or findings on the same issue. In these cases the court requires a super-expert, with a higher scientific and academic level of experts, or orders that the expertise be carried out by a group of experts (three experts), in order to reach the most scientific and professional conclusion, as well as while also respecting the forensic methodology and standards of modern forensic expertise.

The reason why experts come to different conclusions about the same issue should be asked in some directions just as important for experts. Often experts do not have the same model or models available for expertise, then model whether original or not (photocopied, scanned, etc.), as well as different aspects according to the established methodology for expertise ${ }^{2}$.

\footnotetext{
${ }^{1}$ Criminal Procedure Code of R.KosovoNo. 04 / L-123, Article 136 Expertise, Article 137 Decision to engage an expert, Article 138 Expert report, Article 139 Requests for examination of evidence by an expert, Article 140 Statement of expert in preliminary procedure, Article 141 Engagement of expert by the defendant, Article 142 Controversy between experts..

2 Sedat Krasniqi PhD, Ligjerues universitar në lëndët e Kriminalistikës, Kolegji "FAMA"-Prishtinë, Ekspert Kriminalist "Qendra për Ekspertime Shkencore Kriminalistike" - Shoqata e Shkencave Ligjore, Drejtor Ekzekutiv, Kosovë, 2016.
} 


\section{Contradictory cases in the appointment of experts - Case Study in Albania}

It is quite interesting to mention some contradictory or "handicap" cases concerning the appointment of experts found in the current practice of the Albanian courts. Mention, for example:

1. The assignment by the Court of a forensic expert under the General Directorate of State Police for the performance of a given expertise in a criminal case, a case in which, in our view, there is a clear conflict of interest. This, since in this case the criminal expert being a police officer, according to the law "On State Police", has at the same time the attributes of the Judicial Police, while in the Code of Criminal Procedure, it is emphasized that the Judicial Police performs investigative actions through its agents, ordered or delegated by the prosecutor. Can such an expert provide enough credibility?

\section{Liabilities to experts}

a. Experts must be professionally skilled and competent in the tasks that the courts undertake to carry out their expertise, to comply with all requirements and rules assigned in the methodology for carrying out the expertise. Carefully analyze the requirements and questions posed before the expertise, and provide professional, well-reasoned scientific answers.

b. Experts must be objective and impartial; they must be science-based, it is necessary to open their eyes and ears, not to believe characteristically blindly, to apply the Cartesian method, to lack confidence in memory, to think clearly before writing accurately, the art of inference consists in thinking.

\section{To the Court's attention}

It is very important for us to be guided by the principle that: "Conducting a qualitative expertise rests on the need to carry out an expertise". It is therefore equally important that we make sure that we are hiring the right experts for the job at all times, experts who are up-to-date and able to utilize both theory and practice on expertise.

It is the expert's responsibility that before accepting the task and the issues required for resolution, it is stated whether he is adequately qualified to perform the required expertise or not, where the process of submitting the expert's professional competence to the court (in the form of presenting and submitting to the court a copy of his / her CV, giving the court, but also the parties, a preliminary assessment in all ethical and professional aspects), which must necessarily precede his or her task.

At the same time, it is the duty of the court to verify in advance whether the proposed (or sent) expert is qualified and whether there are conditions which may affect the objectivity and quality of the expertise to be performed by him in relation to the task entrusted or not.!

One of our main goals in this paper is to raise standards towards obtaining expert evidence, objectively and without various influences, as well as on a scientific basis. Justice (Article 224/ d of the Code of Civil Procedure), with control over the criteria, competence, ethics and reputation of each of them, is a very important positive step in this regard.

\section{Meaning of methodology}

When referring to methodology, the term "method doctrine" is summarized, that is, the study of the basic theoretical concepts underlying a given discipline and the techniques with which its foundations should be applied in practice. The methodology adjusts and defines the criteria according to which it must be objectively processed for the correct application of knowledge pertaining to a given discipline, a defined domain of human cognition.

The method, which is the practical result of this doctrine, becomes the systematic and functional criterion for proceeding in a kind of theoretical-practical activity in correlation with the finalization of its object.

The foregoing immediately distinguishes some primary elements in the function of the method, among which the most important are:

1 Rationality is an indispensable element when the procedures and actions aimed at solving certain problems are to be outlined;

, Systematicity, which must consist of the rigor and style and order of the stages and implementations that requires a particular activity. 
1 The search for the elements needed to carry out theoretical-practical activity to the end. Search is definitely the most essential element in the terminology "method" because it comes from the Greek word "methodos" which means exactly "search".

In any scientific proceeding, or merely preliminary examination, there would be no appreciable result in the objective plan if it is not proceeded according to the above elements: rationality, systematicity and research. That is, in any descriptiveverification or application-scientific procedure is necessary way to follow the method ${ }^{1}$.

\section{Methodology in Manuscript Expertise.}

The methodology applied in the graphic expertise takes into account the concepts discussed above.

The scope of the study is determined by the request formulated by the proceeding authority / institution that requires the expertise to be carried out. The requirement in each one precisely defines the specific object of expertise, but otherwise it is good for the expert (and the expert of course) to clearly specify the issues raised for resolution, since they also set methodological criteria that will be implemented during the examination phase. It is now defined that the object and the method are organically linked. Depending on the formulation of the request and the type of work that the expert must perform to resolve the particular case.

The expertise methodology specifies 3 (three) types of activities that are interrelated and that the expert must necessarily respect and implement.

Adherence to and application of working procedures, and moreover observance of technical and legal norms, based on graphical manuscript expertise.

Knowledge and application of scientific concepts to be used for the correct interpretation of graphical manuscript phenomena.

Recognition and adherence to epistemological criteria ${ }^{2}$, which must necessarily be followed and applied in the graphical examination, in correlation with the object of study specified in the issues raised for resolution by the proceeding authority.

All these actions are performed in compliance with the norms that regulate them and which the expert must necessarily recognize. Knowledge of the scientific concepts underlying the interpretation of graphical phenomenology is necessary for the correct analysis of the graph line as well as for the correct interpretation of the features that are evidenced ${ }^{3}$. If this knowledge is lacking, the methodology remains defective because the expert is unable to interpret the manuscript's graphic characteristics correctly.

Recognition and adherence to epistemological criteria at the examination stage are also necessary to concretize the procedure criteria, to use the necessary terminology, for the coherence of the demonstrations, but not to be contradicted.

The expert must be well aware of the disciplines underlying the correct interpretation of graphical phenomena, but if he fails to explain demonstrations of objective concepts according to the criteria of procedures required by epistemology of science, his expertise will be mediocre rather than professional.

The methodology applied in graphical expertise, takes into account the concepts discussed above and commonly uses the following methods:

- analytical methods;

- comparative methods;

- signaling methods;

\footnotetext{
${ }^{1}$ Ekzaminimi Grafik i Doreshkrimeve - METODIKË", Viktor Hajdari, 2018

2 L'Epistemology (from the Greek episteme, "safe knowledge" or "science" the logos) is that branch of philosophy that is occupied with the conditions through which we can have scientific recognition and some methods to achieve a knowledge of such.

${ }^{3}$ Vettorazzo Bruno, (1998) -Manual shkencor i ekspertimit grafik mbi baza grafologjike, Milano, Itali.
} 
- deductive-logical methods.

\section{Manuscript expertise}

Document and handwriting experts consistently commemorate the golden rules: two individuals never write alike. This is not to say that there is no similarity in the manuscript of the two individuals, for there are many factors that constitute the general character of one's writing. According to these golden rules, which are based on numerous scientific researches, and especially on twins, they provide strong support for identifying or eliminating a person in various disputes and solving complex criminal matters. The method of direct comparison between suspicious material and known material is functional by relying on auxiliary instruments. Manuscript experts agree that manuscript expertise passes through the following stages ${ }^{1}$.

Preliminary Case Study - Firstly, the court's order directing the expertise to be sought is reviewed. Evidence review (litigation subject to expertise) is done to determine whether it is freely written under normal circumstances by appropriate means or that the writing is appropriate. Preliminary study of disputed writing is important, where the expertise methodology then has its specifics for the examination of writing. It is important to study the general and specific characteristics in order to ascertain whether the writing was written under appropriate conditions or by means of, whether it was influenced by pathological or psychological factors (age, illness, alcohol influence) and has the script been attempted to disguise it or not. This is the ultimate balance of string and shape size, which is critical in signature comparisons, not just the matching of individual elements ${ }^{2}$. So we have to come to the conclusion that writing is written naturally or freely and not by factors like the ones mentioned above or other impeller factors.

Examination of the Contested Manuscript - After studying the script whether it is written freely (naturally) or whether it has been altered, the character analysis is done throughout the manuscript, beginning with the group characteristics and then the individual characteristics. Characterization is done directly in the copy of the original or can also be done in a worksheet, documenting the features individual with identification marks ${ }^{3}$.

\section{ACE-V Methodology}

Although there is an element of subjectivity in the area of forensic examination of documents, the investigator's findings reflect more than mere thought. The examiner's findings should reflect a systematic compilation and evaluation of all observed physical facts, in light of the basic rules of identification and personal experience. The ACE-V methodology is one such way of organizing and evaluating data for the purposes of scientific classification and comparison.

ACE-V is an acronym for the forensic methodology developed analogous to the scientific method, which is used to "individualize or exclude phenomena or objects originating from an identical source or appearing to be in the same source 4 . A goal for analysis, or a process in which the information collected is analyzed for specificity and relevance; $C$ represents the comparison stage, or the stage at which the examiner's predictions are valid, invalid or unconvincing; and $E$ stands for evaluation, which relies on the training and experience of examiners to evaluate the information generated in the ACE-V analysis and comparison phases The final stage in the ACE-V methodology is verification, with another expert document expert reassessing the original hypothesis using the process ACE to determine if it is possible to individual formally isolate or exclude certain sets of information used for comparison.

\section{What is forensic examination of documents?}

Forensic Document Examination The FDE is a forensic science discipline in which expert examiners evaluate documents that are contested in the legal system. "Documents" can be broadly defined as any material that carries signs, signs or symbols intended to convey a message or meaning to someone. Document screening involves comparing a document or aspects of a document to a set of known standards (i.e., authentic copies). The purpose of a forensic document examiner is to systematically evaluate the attributes and characteristics of a document to discover how it has been prepared or modified.

\footnotetext{
1 Saferstein.R,Criminalistics, $9^{\text {th }}$ edition,2014,page 498-499

2 Slyter.S,Forensic Signature Examination,1995,page 10

3 Kelly Seman J,Scientific Examination of Questioned Documents,New York,USA,2006,page 133

${ }^{4}$ Craig Coppock, Definimi Universal i ACE-V Azhurnuar, 6-19-2012
} 


\section{Training and qualification of forensic document examiners.}

There are two internationally recognized programs that accredit forensics laboratories: the American Society of Crime Laboratories' Accrediting Laboratory Accreditation Committee and the ASI-ASQ National Accreditation Committee. These accreditation programs ensure that forensic laboratories meet established quality standards and employ expert forensic investigators. Document forensics should be performed by a forensic examiner (FDE or "Document Examiner"). Currently, there is no federal licensing for forensic document examiners; however, in the United States, the American Board of Legal Examiners (ABFDE) has issued guidelines and issued a certificate of qualification. complete either a curriculum in a recognized forensics laboratory or with an established private practice examiner.

The National Association of Document Examiners (NADE) was founded in 1979 to promote the interests of document examiners. Although there are no specific college studies or degrees in the forensic exam, scientific training is encouraged and continuing education courses should remain in good standing with the committees mentioned ${ }^{1}$.

\section{References}

[1] Craig Coppock, Definimi Universal i ACE-V Azhurnuar, 6-19-2012

[2] Criminal Procedure Code of R.KosovoNo. 04 / L-123, Article 136 Expertise, Article 137 Decision to engage an expert, Article 138 Expert report, Article 139 Requests for examination of evidence by an expert, Article 140 Statement of expert in preliminary procedure, Article 141 Engagement of expert by the defendant, Article 142 Controversy between experts..

[3] Dr.Fatmir Tartale, Ekspertimi si prove në procedimin penal, Tiranë 2008, f 13-14

[4] Ekzaminimi Grafik i Doreshkrimeve - METODIKË", Viktor Hajdari, 2018

[5] Kelly Seman J,Scientific Examination of Questioned Documents,New York,USA,2006,page 133

[6] Kodi i procedures penale I Republikës së Shqipërisë, Tiranë 2004, f. 83 -117.

[7] L'Epistemology (from the Greek episteme, "safe knowledge" or "science" the logos) is that branch of philosophy that is occupied with the conditions through which we can have scientific recognition and some methods to achieve a knowledge of such.

[8] Practice forensics applications in USA

[9] Saferstein.R,Criminalistics,9th edition,2014,page 498-499

[10] Sedat Krasniqi PhD, Ligjerues universitar në lëndët e Kriminalistikës, Kolegji "FAMA"-Prishtinë, Ekspert Kriminalist "Qendra për Ekspertime Shkencore Kriminalistike" - Shoqata e Shkencave Ligjore, Drejtor Ekzekutiv, Kosovë, 2016.

[11] Sedat Krasniqi PhD, Ligjerues universitar në lëndët e Kriminalistikës, Kolegji "FAMA"-Prishtinë, Ekspert Kriminalist "Qendra për Ekspertime Shkencore Kriminalistike" - Shoqata e Shkencave Ligjore, Drejtor Ekzekutiv, Kosovë, 2016.

[12] Sedat Krasniqi PhD, University Lecturer in Criminalistics, College "FAMA" -Prishtina, Criminal Expert. "Center for Forensic Science Expertise" - Association of Forensic Sciences, Executive Director, Kosovo, 2016.

[13] Sedat Krasniqi, PhD, University of Sarajevo, Faculty of Criminalistics, Criminology and Security Studies, Sarajevo BiH, 2016/17.

[14] Slyter.S,Forensic Signature Examination,1995,page 10

[15] Vettorazzo Bruno, (1998) -Manual shkencor i ekspertimit grafik mbi baza grafologjike, Milano, Itali.

\footnotetext{
${ }^{1}$ Practice forensics applications in USA
} 